\title{
INJUNCTIVE RELIEH IN PATENT INFRINGEMENT SUITS
}

To enable a patentee to protect his "right to exclude others from making, using, or selling" 1 his invention, Congress has granted him a "remedy by civil action for infringement" 2 in the federal courts. During the course of litigation, these courts "may grant injunctions in accordance with the principles of equity to prevent the violation of any right secured by patent, on such terms as the court deems reasonable," ${ }^{3}$ including temporary relief to the patentee. ${ }^{4}$

The granting of temporary injunctive relief on the basis of incomplete facts may often settle the ultimate issues immediately and cause irreparable injury to the enjoined party. ${ }^{5}$ If a temporary injunction is unwarranted, a few years will probably elapse before final determination that the injunction was improvidently granted. ${ }^{6}$ By this time, the alleged infringer's loss of competitive advantage over the patentee may be incapable of repair by money damages. ${ }^{7}$ On the other hand, irreparable injury may befall the charging party if the temporary injunction is not issued. For example, the delay until trial on the merits can encourage willful infringement of a patent near its expiration date, irreparably injuring a patentee by shortening his patent's effective life. ${ }^{8}$ A similar effect occurs if the patent's primary utility lies in its first few years of existence.

The American patent system gives all inventors the same "reward" of a seventeen year monopoly irrespective of the extent of contribution or the stimulus needed to induce invention or exploitation. Courts must grant or deny injunctions for the entire term even if their own political and economic predilections favor a standard of invention that would result in fewer patent monopolies. ${ }^{9}$ This judicial dilemma may at times lead to unnecessary in-

135 U.S.C. $\$ 154$ (1958).

235 U.S.C. $\$ 281$ (1958).

335 U.S.C. $\$ 283$ (1958).

4 See generally 3 Robinson, Patents $\$ \$ 1168-1220$ (1890); 3 Waiker, Patents $\$$ 765-820 (Deller's ed. 1937, Supp. 1963) ; Note, The Enforcement of Rights Against Patent Infringers, 72 HARv. L. REv. 328, 339-43 (1958).

5 See ibid.; cf. Note, Temporary Injunctive Relief Under Section 10(l) of the Taft-Hartley Act, 111 U. PA. L. Rev. 460 (1963).

6 A Senate subcommittee study showed that in fiscal 1959 the median time from filing of complaint to trial in 86 federal districts was 15.3 months, and in the Southern District of New York, where many patent infringement suits are brought, the time was 26.7 months. The time between issue and trial was on the average 10.3 months in these same 86 districts, and 19.1 in the Southern District. STAFF of Subcoms. on Patents, Tradeararks \& Copyrights, Senate Comra. on the Judiciary, 86rh Cong., 2D Sess., AN Analysis of Patent Litigation Statistics 3 (Comm. Print 1961).

7 Ibid.

8 Ibid.

8 Stedman, Inzention and Public Policy, 12 LAw \& Contemp. Prob. 649, 661-71 (1947). 
validation of patents, ostensibly to protect the public despite injury to the patentee. $^{10}$ At the very least, the overplay of political and economic considerations in this "all or nothing" determination of the standard and scope of invention impedes adjudication of applications for permanent injunctive relief and to a lesser degree also interferes with consideration of applications for temporary relief. Over the last one and one-half centuries the broad equitable power possessed by the federal judiciary and manifested in unchanging articulated requirements for temporary and permanent injunctive relief ${ }^{11}$ has masked broad shifts in the standards applied, possibly reflecting economic and political currents within the judiciary and the community as a whole.

\section{The Statutory Framework}

Obedient to the constitutional mandate "to promote the Progress of Science and useful Arts, by securing for limited Times to Authors and Inventors the exclusive Right to their respective Writings and Discoveries," 12 the first Congress authorized the granting of patents. ${ }^{13}$ Congress, however, did not originally provide a forum for equitable enforcement of patent rights. ${ }^{14}$ Therefore, the federal courts encountered jurisdictional limitations on their exercise of ordinary equitable powers in favor of patentees. ${ }^{15}$ To alleviate these difficulties, Congress passed the Patent Act of 1819, granting the federal courts "upon any bill in equity [the] . . . authority to grant injunctions, according to the course and principles of courts of equity . . . on such terms and conditions as the said courts may deem fit and reasonable." 16 Despite myriad changes in other areas of the patent laws, the federal equity jurisdiction over injunctive relief has remained essentially unchanged since its enactment.

\section{Preliminary Injunctive Relief Against Infringers}

\section{A. The Early Standards}

The grant or denial of temporary injunctive relief depends upon the court's "sound discretion." This judgment in turn requires consideration of the comparative injuries to the parties if relief is granted or withheld until the completion of trial. ${ }^{17}$ However, courts must first isolate the elements requisite to permanent injunctive relief in order to assess the prob-

10 See $i d$. at 667.

11 See Bump, Preliminary Injunctions in Patent Cases, 5 CENT. L.J. 418 (1877); Note, The Enforcement of Rights Against Patent Infringers, 72 HARv. L. Rev. 328 (1958).

12 U.S. Const. art. I, $\$ 8$.

13 Act of April 10, 1790, ch. 7, §§1-7, 1 Stat. 109.

14 See 3 Walker, Patents $\$ 538$ (Deller's ed. 1937).

15 See Livingston v. Van Ingen, 15 Fed. Cas. 697 (No. 8420) (C.C.D.N.Y. 1811).

18 Act of Feb. 15, 1819, ch. 19, 3 Stat. 481-82 (1819), as amended.

17 See Rice \& Adams Corp. v. Lathrop, 278 U.S. 509, 514 (1929). 
ability of the applicant's success at trial. By mid-nineteenth century the generally recognized elements included the applicant's title to the patent, the patent's validity, and its infringement by the defendant. ${ }^{18}$ But the minimum quantum of proof required for each of these elements to support injunctive relief was not yet settled.

\section{Title}

Since establishment of title is usually not a difficult process, courts insisted on a clear showing-in effect, they applied a "no reasonable doubt" standard. Title was ordinarily ascertainable directly from the letters patent or from an assignment to the plaintiff; ${ }^{19}$ some courts also construed conflicting documents, if necessary, to resolve reasonably simple factual disputes of title. ${ }^{20}$

\section{Validity}

The most persuasive evidence of validity, if a "no reasonable doubt" test were applied, was an adjudication of the patent's validity in a prior adversary proceeding. ${ }^{21}$ Although not guaranteeing an ultimate holding of the patent's validity as between the present parties, prior adjudication of validity is the result of a full court hearing, including thorough examination of the relevant prior art. However, since validity, as well as infringement, is ordinarily not so readily ascertainable, courts also accepted tests less restrictive than the "no reasonable doubt" standard to evaluate these elements at preliminary injunction proceedings. A sufficient demonstration of public acquiescence in the invention might support a presumption of validity on the ground that informed members of the public acted as though the patent were valid.22 Two common factual situations establishing acquiescence were that no competitors challenged the patentee's continued profitable trade in the patented process or article, ${ }^{23}$ or that for a long period all makers, users, and sellers of the device operated only under license from the patentee. ${ }^{24}$ Accepting a patent's validity on the basis of public acquiescence can at most be described as "reasonable cause to believe" the

18 See Bump, supra note 11, at 418.

19 See Mowry v. Grand St. \& N.R.R., 17 Fed. Cas. 937 (No. 9893) (C.C.E.D. N.Y. 1872) (dictum) ; 3 Robinson, PATENTS $\$ 1190$ (1890); cf. Waterman v. MacKenzie, 138 U.S. 252 (1891) (exclusive license).

20 See Clum v. Brewer, 5 Fed. Cas. 1097, 1102 (No. 2909) (C.C.D. Mass. 1855).

21 See Potter v. Muller, 19 Fed. Cas. 1170, 1171 (No. 11334) (C.C.S.D. Ohio 1864); Orr v. Littlefield, 18 Fed. Cas. 837,839 (No. 10590) (C.C.D.N.H. 1845). 1853).

22 See Goodyear v. Central R.R., 10 Fed. Cas. 664, 666 (No. 5563) (C.C.D.N.J.

23 Sargent v. Seagrave, 21 Fed. Cas. 505 (No. 12365) (C.C.D.R.I. 1855) (patentee made and sold 105,000 patented machines in 2 year period); Foster v. Moore, 9 Fed. Cas. 563 (No. 4978) (C.C.D. Mass. 1852) (patentee made and sold 150 patented machines in 8 year period).

24 See Thompson Elec. Weiding Co. v. Two Rivers Mfg. Co., 63 Fed. 120 (C.C.E.D. Wis. 1894) ; Hat-Sweat Mfg. Co. v. Davis Sewing Mach. Co., 32 Fed. 481 (C.C.N.D.N.Y. 1887); cf. Grover \& Baker Sewing Mach. Co. v. Williams, 11 Fed. Cas. 83, 84-85 (No. 5847) (D. Mass. 1860) (dictum). 
patent's validity, since commercial success, even when combined with abstention of others from the field, does not directly substantiate the elusive quality of invention essential to a valid patent. ${ }^{25}$ This test also ignores substantive defenses to validity that the defendant might successfully raise upon trial. ${ }^{26}$

Only in rare instances did the courts look beyond prior adjudication or public acquiescence for evidence of validity. Occasionally they granted patentees preliminary relief if examination of the overall circumstances revealed unethical or inequitable conduct by the alleged infringer. ${ }^{27} \mathrm{But}$ a sufficient showing of validity always demanded more than mere exhibition of the letters patent. ${ }^{28}$

\section{Infringement}

A common judicial verbalization of a sufficient preliminary showing of defendant's infringement was that infringement must be "clear." ${ }^{29}$ To achieve this result the court first had to determine the scope of the plaintiff's patent, either by relying upon the construction given it in a prior adjudication, ${ }^{30}$ or, if none were available, upon the court's own possibly superficial evaluation. ${ }^{31}$ The court then had to decide whether the defendant infringed this construction of the plaintiff's patent. ${ }^{32}$ These determinations frequently entailed complex interpretations of conflicting affidavits ${ }^{33}$ and left room for doubt that the interpretations would be sustained after full development of expert testimony and other evidence at the ultimate trial upon the merits. Thus, to establish infringement for the purposes of preliminary relief, the courts required only a showing that gave them "reasonable cause to believe" the plaintiff's claim.

\section{Irreparable Injury}

Once the complainant established the elements of a prima facie case, ${ }^{34}$ the court still had to decide whether he was entitled to preliminary injunc-

25 See 35 U.S.C. $\S \S 101,103$ (1958).

26 See, e.g., 35 U.S.C. $\$ 102$ (1958) (domestic and foreign anticipation; patentee not actual inventor).

27 See Sickels v. Mitchell, 22 Fed. Cas. 74 (No. 12835) (C.C.S.D.N.Y. 1857). 28 See Edward Barr Co. v. New York \& New Haven Automatic Sprinkler Co., 32 Fed. 79 (C.C.S.D.N.Y. 1887); Booth v. Garelly, 3 Fed. Cas. 883 (No. 1646) (C.C.S.D.N.Y. 1847).

29 See, e.g., Allis v. Stowell, 15 Fed. 242 (C.C.E.D. Wis. 1883) (injunction denied); Cross v. Livermore, 9 Fed. 607 (C.C.D.R.I. 1881) (injunction denied); Kirby Bung Mfg. Co. v. White, 1 Fed. 604 (C.C.E.D. Mo. 1880) (injunction denied); cf. Standard Elevator Co. v. Crane Elevator Co., 56 Fed. 718 (7th Cir. 1893).

30 See Mallory Mfg. Co. v. Hickok, 20 Fed. 116 (C.C.D. Conn. 1884). But see Many v. Sizer, 16 Fed. Cas. 690 (No. 9057) (C.C.D. Mass. 1849).

31 See Coburn v. Clark, 15 Fed. 804 (C.C.E.D. Mo. 1883) ; Clum v. Brewer, 5 Fed. Cas. 1097 (No. 2909) (C.C.D. Mass. 1855).

32 See Many v. Sizer, 16 Fed. Cas. 690 (No. 9057) (C.C.D. Mass. 1849).

33 See Blanchard v. Reeves, 3 Fed. Cas. 638 (No. 1515) (C.C.E.D. Pa. 1850); Gibson v. Van Dresar, 10 Fed. Cas. 329 (No. 5402) (C.C.N.D.N.Y. 1850); cf. Morse Fountain Pen Co. v. Esterbrook Steel Pen Mfg. Co., 17 Fed. Cas. 875 (No. 9862) (C.C.D.N.J. 1869).

34 See 3 WaLKER, op. cit. supra note $14, \S 773$. 
tive relief. The customary equity test for preliminary relief involved balancing plaintiff's probable success at trial on the merits against the likely injuries to plaintiff, if he were denied relief until final trial, and to defendant, if immediate relief were granted. ${ }^{35}$ However, in patent litigation many courts automatically preserved statutory patent monopolies by assuming that the irreparable injury requisite to a preliminary injunction necessarily followed a finding of "reasonable cause to believe" that defendant infringed plaintiff's valid patent. ${ }^{36}$ The rigidity of this approach was mitigated by many courts only if the defendant could establish affirmatively that the plaintiff would not suffer irreparable injury until the final trial-for example, by a showing that infringement did not harm plaintiff in light of the manner in which plaintiff was using the monopoly. The defendant might then be given the alternative of posting a bond to cover possible damages against him. ${ }^{37}$ Courts have taken this approach upon finding that the plaintiff had relinquished exclusive control by licensing his patent to others ${ }^{38}$ or that he intended not to use his patent except to keep it from others. ${ }^{39}$ Moreover, some courts even seemed to adopt the traditional equity balance of convenience or comparative injury rationale ${ }^{40}$ of considering not only the impact on the plaintiff if the injunction were denied, but also the harm to the defendant if it were granted.4 However, in this early period the strong disposition to grant preliminary injunctions when-

35 See 1 Hige, Injunctions $\$ 13$ (4th ed. 1905) ; 4 Pomeroy, EQuity JurisPRUDENCE $\$ \$ 1359,1359 \mathrm{a}$ (5th ed. 1941) ; McKean, The Balance of Convenience Doctrine, 39 Dick. L. REv. 211 (1935).

${ }^{36}$ See, e.g., Hussey v. Whitely, 12 Fed. Cas. 1067 (No. 6950) (C.C.S.D. Ohio 1860) ; Ely v. Monson \& B. Mfg. Co., 8 Fed. Cas. 604 (No. 4431) (C.C.D. Mass. 1860); Sickels v. Mitchell, 22 Fed. Cas. 74 (No. 12835) (C.C.S.D.N.Y. 1857) ; Sickels v. Tileston, 22 Fed. Cas. 77 (No. 12837) (C.C.S.D.N.Y. 1857); Gibson v. Van Dresser, 10 Fed. Cas. 329 (No. 5402) (C.C.N.D.N.Y. 1850) ; Conover v. Mers, 6 Fed. Cas. 322 (No. 3123) (S.D.N.Y. 1868).

37 See American Middlings Purifer Co. v. Christian, 1 Fed. Cas. 683 (No. 307) (C.C.D. Minn. 1877); Forbush v. Bradford, 9 Fed. Cas. 422 (No. 4930) (C.C.D. Mass. 1858). Compare American Middlings Purifier Co. v. Atlantic Milling Co., 1 Fed. Cas. 675 (No. 305) (C.C.E.D. Mo. 1877).

38 See Howe v. Morton, 12 Fed. Cas. 663, 670 (No. 6769) (C.C.D. Mass. 1860); cf. Colgate v. Gold \& Stock Tel. Co., 6 Fed. Cas. 76, 81 (No. 2991) (C.C.S.D.N.Y. 1879) ; Hodge v. Hudson R.R., 12 Fed. Cas. 276, 278 (No. 6560) (C.C.S.D.N.Y. 1868).

39 See How v. Boston Daily Advertiser Corp., 14 Fed. 914 (C.C.D. Mass. 1883). See also Hoe v. Knap, 27 Fed. 204, 212 (C.C.N.D. Ill. 1886); Dorsey Harvester Revolving Rake Co. v. Marsh, 7 Fed. Cas. 939, 945 (No. 4014) (C.C.E.D. Pa. 1873). 40 See, e.g., Gilbert \& Barker Mfg. Co. v. Bussing, 10 Fed. Cas. 348 (No. 5416) (C.C.S.D.N.Y. 1875) ; Dorsey Revolving Harvester Rake Co. v. Bradley Mfg. Co., 7 Fed. Cas. 946 (No. 4015) (C.C.N.D.N.Y. 1874); Morris v. Lowell Mfg. Co., 17 Fed. Cas. 946 (No. 4015) (C.C.N.D.N.Y. 1874); Morris v. Lowell Mfg. Co., 17 Fed. Cas. 822 (No. 9833) (C.C.D. Mass. 1866); Essex Hosiery Mffg. Co. v. Dorr Iff. Co., 8 Fed. Cas. 791 (No. 4533) (C.C.D. Mass. 1846); cf. Morris v. Shelbourne, 17 Fed. Cas. 829 (No. 9836) (C.C.E.D.N.Y. 1871).

41 For example, the infringing machinery may contain many costly parts not covered by the plaintiff's patent. See Stainthorp v. Humiston, 22 Fed. Cas. 1035 (No. 13280) (C.C.N.D.N.Y. 1862); Howe v. Morton, 12 Fed. Cas. 663 (No. 6769) (C.C.D. Mass. 1860). But see Westinghouse Air-Brake Co. v. Burton Stock-Car Co., 70 Fed. 619, 621 (C.C.D. Me. 1895). See also Guidet v. Palmer, 11 Fed. Cas. 105 (No. 5859) (C.C.E.D.N.Y. 1872) (public interest against enjoining defendant's use of patent). 
ever the court had "reasonable cause to believe" that plaintiff would succeed in the final trial usually relegated the traditional equity investigation of potential harms in patent infringement suits to the determination of whether to order an injunction or the giving of a bond.

\section{B. Shifts in the Application of Nineteenth Century Standards}

\section{Early Twentieth Century}

During the first few decades of the twentieth century, the required showing for preliminary injunctive relief remained couched in terms of title, validity, infringement, and irreparable injury. But many courts began to demand a greater quantum of proof for each of these elements before granting preliminary relief. This shift is highlighted in City of Grand Rapids $v$. Warren Bros. ${ }^{42}$ The defendants argued that the general trend of authorities compelled a denial of a preliminary injunction or bond because the previously adjudicated patent had not been clearly infringed, and therefore every element of plaintiff's claim was not "so clear that the court can entertain no doubt on the subject." 43 The court, while recognizing growing support in other circuits for defendant's position, ${ }^{44}$ nevertheless held that the plaintiff was entitled to the relief of bond under traditional equity principles, although there was at most "reasonable cause to believe" that defendant infringed.

The retention of the nineteenth century "reasonable cause to believe" standard in Grand Rapids received no support in other circuits. ${ }^{45}$ They instead continued to strengthen the requirements of proof toward a "no reasonable doubt" standard. Thus, although a prior adjudication still sufficed to establish validity, ${ }^{46}$ plaintiffs often could not sustain validity upon a public acquiescence theory simply by showing that they had practiced the invention for a few years with commercial success and without competition. Courts now required a clear showing of public acquiescenceamounting to proof that the industry needed the device but did not adopt it in deference to the plaintiff's patent. ${ }^{4 \pi}$ The courts also increased the

42196 Fed. 892 (6th Cir. 1912).

43 Id. at 894. (Emphasis added.) The defendant's argument continued that upon requisite proof of title, validity, and infringement the injunction must issue regardless of irreparable injury in order to maintain the statutory monopoly. Ibid.

44 See Southern Pac. Co. v. Earl, 82 Fed. 690, 691 (9th Cir. 1897) (dictum); cf. Blount v. Societe Anonyme Du Filtre Chamberland Systeme Pasteur, 53 Fed. 98 (6th Cir. 1892) (question concerning infringement; complainant more likely to be irreparably injured than alleged infringer; injunction granted).

45 See cases cited notes $46-48$ infra.

46 See, e.g., Fireball Gas Tank \& Illuminating Co. v. Commercial Acetylene Co., 198 Fed. 650, 653 (8th Cir. 1912) ; General Elec. Co. v. Minneapolis Elec. Lamp Co., 10 F.2d 851 (D. Minn. 1924).

47 See Adam v. Folger, 120 Fed. 260, 261-62 (7th Cir. 1903); American Coat Pad Co. v. Phoenix Pad Co., 113 Fed. 629 (4th Cir. 1902) (alternative holding); Keasbey \& Mattison Co. v. Phillip Carey Mfg. Co., 110 Fed. 747 (C.C.S.D.N.Y. 1901). But cf. Crescent Specialty Co. צ. National Fireworks Distrib. Co., 219 Fed. 130 (6th Cir. 1915) (injunction granted, no bond, with "fair probability" of validity of patent on substantial public acquiescence). See also Packard Paper Box Co. v. O. B. Andrews Co., 67 F.2d 783 (1st Cir. 1933). 
necessary showing of infringement by requiring that it also be clearly proved. ${ }^{48}$ The effect was a greater judicial reluctance to determine from conflicting affidavits the patent's scope and the likelihood that defendant infringed it. However, the shift to more stringent standards was confined to the elements of title, validity, and infringement. A presumption of irreparable injury, based on the notion of uncritically preserving the statutory monopoly, still frequently followed as of course once plaintiff established the first three elements of his claim. ${ }^{49}$ Courts accordingly became increasingly hesitant to let defendants substitute bond for injunction. ${ }^{50}$

Another trend, suggested in a few prior cases, ${ }^{51}$ but contrary to the general tightening of standards for preliminary relief, appeared during this period. In Boyce v. Stewart-Warner Speedometer Corp., $5 \mathbf{2}$ the patentee charged the defendant with infringement but, due to the patent's recent issuance, could establish validity by neither prior adjudication nor public acquiescence. $^{53}$ However, the defendant's device was an obvious copy of the plaintiff's patented product; the court found "no doubt" $5-4$ that the plaintiff's patent was valid and issued a preliminary injunction. Therefore, the plaintiff, presenting a case of "no reasonable doubt" on the issues of title, infringeinent, and irreparable injury, sustained his right to an injunction, although he showed only that his patent was "more probably than not" valid, this presumption of validity flowing from the unattended letters patent. $^{55}$ The copying itself probably did not have a sufficiently close resemblance to "palming off" to support an independent charge of unfair

48 See, e.g., A. B. Dick Co. v. Barnett, 277 Fed. 423 (2d Cir. 1921) ; Layne v. Getty, 222 Fed. 917 (5th Cir. 1915) (per curiam); Wright Co. v. Herring-Curtiss Co., 180 Fed. 110 (2d Cir. 1910) (per curiam); Summerhays v. Scheu Mfg. Co., 47 F.2d 945 (S.D. Cal. 1930) : Safety Car Heating \& Lighting Co. v. United States Light \& Heat Corp., 233 Fed. 1007 (W.D.N.Y. 1916). See also Anderson \& Writer Corp. v. Hanky Beret, Inc., 40 F.2d 196 (2d Cir. 1930), reversing 36 F.2d 412 (S.D. N.Y. 1929) (lower court found a "clear infringement").

49 See, e.g., Hilditch v. American Bumper Corp., 15 F.2d 451 (E.D.N.Y. 1926); General Elec. Co. v. Wise, 119 Fed. 922 (C.C.N.D.N.Y. 1903). But cf. Landis Tool Co. v. Ingle, 286 Fed. 5,7 (3d Cir. 1923). See also United States Gypsum v. Bestwall Mfg. Co., 290 Fed. 800,801 (7th Cir. 1923).

50 Very few cases during this period granted a bond in lieu of injunction. See Interurban Ry. \& Terminal Co. v. Westinghouse Elec. \& Mfg. Co., 186 Fed. 166 (6th Cir. 1911) (patent only had short time to run). But see Toledo Plate \& Window Glass Co. v. Kawneer Mfg. Co., 262 Fed. 510 (6th Cir. 1920); Universal Gypsum \& Lime Co. v. Haggerty, 21 F.2d 544 (W.D.N.Y. 1927).

51 See Edward Barr Co. v. New York \& New Haven Automatic Sprinkler Co., 32 Fed. 79 (C.C.S.D.N.Y. 1887); Sickels v. Mitchell, 22 Fed. Cas. 74 (No. 12835) (C.C.S.D.N.Y. 1857).

52220 Fed. 118 (2d Cir. 1914).

53 See also McMaster v. Daugherty Mfg. Co., 219 Fed. 219 (3d Cir. 1914); Standard Typewriter Co. v. Standard Folding Typewriter Sales Co., 181 Fed. 500 (2d Cir. 1910); Lambert Snyder Vibrator Co. v. Marvel Vibrator Co., 138 Fed. 82 (C.C.S.D.N.Y. 1905).

54 Boyce v. Stewart-Warner Speedometer Corp., 220 Fed. 118, 120 (2d Cir. 1914). 55 See 35 U.S.C. $\$ 282$ (1958) : A patent shall be presumed valid. The burden of establishing invalidity of a patent shall rest on a party asserting it." In a preliminary injunction hearing this provision allows the plaintiff to succeed on the issue of validity only if the defendant does not contest. See Stewart Stamping Corp. v. Westchester Prods. Co., 119 F. Supp. 92 (S.D.N.Y. 1953). See also Westinghouse Elec. \& Mfg. Co. v. Formica Insulation Co., 266 U. S. 342, 348 (1924). 
competition. ${ }^{56}$ Moreover, even obvious infringement of a patent "pays no tribute to its validity, however much it concedes utility . . .."57 Only the equities of the Boyce situation could have moved the court to ignore the usual requirements. The federal courts have continued to exempt patentees from the normally stringent requirements for demonstrating validity by awarding preliminary injunctions upon a showing that the patent was merely "more probably than not" valid provided that the defendant had engaged in unsavory practices. ${ }^{58}$ These cases seem to rest on an unarticulated and possibly unwarranted ${ }^{59}$ estoppel of defendants to deny the validity of patents during the early stages of the proceedings, if they have blatantly copied publicly disclosed inventions. ${ }^{60}$

\section{Middle Twentieth Century}

The elements of title, validity, infringement, and irreparable injury, and the tests to determine them, have ostensibly remained unaltered since the 1930's, but most courts have completed the shift to more exacting standards to establish each element.

The courts have retained the requirement that the plaintiff's title be established with "no reasonable doubt." The patent, an assignment, or an exclusive license will suffice; affidavits from the party and from absent persons will not. ${ }^{61}$

The standard of "no reasonable doubt" also applies to the patent's validity. ${ }^{62}$ A prior adjudication generally satisfies this test, ${ }^{63}$ but only if

56 See American Safety Table Co. v. Schreiber, 269 F.2d 255, 271-72 (2d Cir. 1959); George O’Day Associates v. Talman Corp., 206 F. Supp. 297 (D.R.I. 1962); 1 Callman, UNfaIR Competition \& TRade-Mfarks $\$ \S 16.2(d), 16.3,16.4$, at 249-6i (2d ed. 1950).

57 Williams Mfg. Co. v. United Shoe Mach. Corp., 121 F.2d 273, 277 (6th Cir. 1941), aff'd, 316 U.S. 364 (1942).

58 Mathieu v. Mitchell Vance Co., 7 F.2d 837 (2d Cir. 1925) ; Milwaukee Printing Co. v. Stover, 290 Fed. 387 (7th Cir. 1923) ("injustice to deny the motion for preliminary relief") ; Schaffer Beits, Inc. v. Trade Accessories, Inc., 53 F. Supp. 266 (S.D.N.Y. 1942) ("circumstances - are so extraordinary"); P. L. \& M. Co. v. Ballagh, 52 F.2d 700 (S.D. Cal. 1931); Anderson Co. v. Welworth Automotive Corp., 46 F.2d 696 (E.D.N.Y. 1931) ("presumption . - entitled to great weight [due to] . . meticulous care . defendant [used in] copy [ing] . . plaintiff's device in all respects"); W. A. Scheaffer Pen Co. v. Worth Featherweight Pen Co., 41 F.2d 820 (S.D.N.Y. 1930) ("under such circumstances the defendant [cannot]

complain"); Anderson \& Writer Corp. v. Hanky Beret, Inc., 36 F.2d 412 (S.D.N.Y. 1929), rev'd on other grounds, 40 F.2d 196 (2d Cir. 1930) ; Tropic-Aire, Inc. v. Jumper, 28 F.2d 631 (D. Minn. 1928); Hutto Eng'r Co. v. Grinder Sales Co., 18 F.2d 985 (E.D. Mich. 1927).

59 See text accompanying notes 106-10 infra.

60 If a person "blatantly copies" a patented device and the patent is subsequently held invalid, this copying cannot be a violation of state unfair competition laws unless the device is deceptively held out as the patentee's. See Sears, Roebuck \& Co. v. Stiffel Co., 376 U.S. 225 (1964).

61 See Edaco Stahlwarenfabrik Ernst Darman \& Co. v. Hill Novelties Mfg. Corp., 185 F. Supp. 621 (S.D.N.Y. 1960) (alternative holding).

62 See, e.g., Heyman Mfg. Co. v. Electrix Corp., 200 F. Supp. 217 (D.R.I. 1961); Tyrolean Handbag Co. v. Empress Handbag, Inc., 122 F. Supp. 299 (S.D.N.Y. 1953); Olsen v. Baby World, 120 F. Supp. 462 (S.D.N.Y. 1953).

63 See Radio Corp. of America v. Collins Radio Co., 13 F. Supp. 976 (D. Del. 1936) (court would not consider defendant's claim of additional prior art on patent adjudicated valid in many prior suits); text accompanying note 21 supra. 
the prior suit was a fully contested adversary proceeding upon the merits of the patent. ${ }^{64}$ A more exacting concept of public acquiescence is the announced equivalent to a prior adjudication. ${ }^{65}$ Singer Mfg. Co. v. Better Serv. Sezering Mach. Co. ${ }^{68}$ accurately represents the limited role currently accorded public acquiescence. ${ }^{67}$ The court in Singer rejected plaintiff's offer of proof, because it was "not clearly beyond dispute" that its competitors desired the device but abstained believing the validity of plaintiff's patent. $^{88}$ Public acquiescence has been accepted to prove validity during the last two decades only in the case of a "pioneer patent." 69 United States Plywood Corp. v. Zeesman Plywood Corp. ${ }^{70}$ attached great weight to the commercial success of the "pioneer" process during the six years from the patent's issuance until suit and noted that the plywood industry, except for the defendant, acquiesced by licensing it from the plaintiff. ${ }^{\top 1}$ However, a showing of public acquiescence, even for a "pioneer patent" as in United States Plywood, does not seem as convincing as a prior adjudication. The conclusion is unlikely that competitors have investigated the validity of the plaintiff's patent-including such aspects as priority, anticipation, and invention-sufficiently to have decided not to infringe because of the strong likelihood that a court will hold the patent valid.72 The recent reluctance of courts to equate public acquiescence with validity suggests their recognition that this inconclusive evidence does not demonstrate a patent's validity with "no reasonable doubt." Their cautious demands for a prior adversary adjudication of validity have virtually precluded patentees from preliminarily enjoining the first infringers.

The courts have also tightened the required showing of infringement in suits for preliminary injunctions. This strictness is manifested initially
64 Rosenberg v. Groov-Pin Corp., 81 F.2d 46, 47 (2d Cir. 1936) :
The doctrine that in the absence of long acquiescence or adjudication an injunction will not go, is at first blush anomalous in the light of the pre- sumption of validity which courts generally grant to a patent once issued. [However] . . examiners have neither the time nor the assistance to exhaust the prior art; nothing is more common in a suit for infringement than to find that all the important references are turned up for the first time by the industry of a defendant whose interest animates his search. It is a reasonable caution not to tie the hands of a whole art until there is at least the added assurance which comes from such an incentive.

See Blessing v. Gordon Textile, 30 F. Supp. 643 (S.D.N.Y. 1939) (prior adjudication not contesting validity held not controlling).

65 See, e.g., Pacific Cage \& Screen Co. v. Continental Cage Corp., 259 F.2d 87 (9th Cir. 1958) (dictum) ; United States Can Corp. v. American Can Co., 31 F. Supp. 91 (S.D.N.Y. 1940) (dictum) ; Metropolitan Button Works, Inc. v. Jaffe, 19 F. Supp. 860 (S.D.N.Y. 1937) (dictum).

68 131 F. Supp. 146 (S.D.N.Y. 1955).

67 See also Artmoore Co. v. Dayless Mfg. Co., 100 F. Supp. 110 (N.D. Ill. 1951). 68131 F. Supp. 146, 147 (S.D.N.Y. 1955).

69 A "pioneer patent" represents a decided advance over the existing state of the art opening up a new field of endeavor. Cf. United Shoe Mach. Corp. v. Industrial Shoe Mach. Corp., 223 F. Supp. 826, 834 (D. Mass. 1963).

7084 F. Supp. 78 (S.D. Cal. 1949).

$71 \mathrm{Id}$. at 82 .

72 See Rosenberg v. Groov-Pin Corp., 81 F.2d 46 (2d Cir. 1936); text accompanying notes $21-24$ supra. 
in construing the scope of the allegedly infringed patent. Despite clear validity deriving from prior adjudication, a court may now more carefully examine the claims allowed in the prior adjudication to be sure that it is "palpably and obviously clear" 73 that their scope includes the allegedly infringing device. ${ }^{74}$ The strong showing has been described as "in effect . . . the equivalent of a summary judgment ...."75 Some courts have refused even to consider the question of infringement if affidavits were submitted from both sides. ${ }^{\text {T }}$

Even if the complainant satisfies current requirements by establishing title, validity, and infringement beyond a reasonable doubt, ${ }^{77}$ a preliminary injunction no longer inevitably follows by presuming irreparable injury from defendant's continued infringement. ${ }^{78}$ Heyman $\mathrm{Mfg}$. Co. v. Electrix Corp. ${ }^{79}$ illustrates a denial of preliminary injunction for clear infringement of a previously adjudicated patent, because the defendant did not establish that "he will suffer injury during the pendency of the proceedings, which is certain and irreparable, if the preliminary injunction is denied." 80 Irreparable injury might be indicated by a permanent loss of market position, as manifested by loss of sales resulting from a denial of the relief. ${ }^{81}$ But this loss may be difficult to establish as between habitual competitors roughly similar in size, since the presumption is strong that their interrelationship will continue without an injunction until the trial on the merits. ${ }^{82}$ Another portent of potential irreparable injury is a clear indication that the defendant will be financially unable to respond in damages. ${ }^{83}$

73 Collins v. Wallin, 66 F. Supp. 687, 689 (D. Mass. 1946) ; see Owens v. American Sterographic Corp., 116 F. Supp. 406, 409 (S.D.N.Y. 1953) ; Ganter v. Unit Venetian Blind Supply Corp., 87 F. Supp. 338 (S.D. Cal. 1949).

74 Leavitt v. McBee Co., 124 F.2d 938, 940 (1st Cir. 1942).

75 Superior Elec. Co. v. General Radio Co., 194 F. Supp. 339, 343 (D.N.J. 1961); see 7 Moore, Federal Practice $\llbracket 65.04$, at 1640 (2d ed. 1955).

76 See, e.g., Superior Elec. Co. v. General Radio Corp., supra note 75, at 343; Burroughs v. Hardee, 126 U.S.P.Q. 471 (E.D.S.C. 1960); cf. Owens v. American Sterographic Corp., 116 F. Supp. 406, 409 (S.D.N.Y. 1953). Compare Schick Dry Shaver, Inc. v. Nicholl, Inc., 21 F. Supp. 731 (S.D. Cal. 1937) (preliminary injunction granted), aff'd, 98 F.2d 511 (9th Cir. 1938), with Schick Dry Shaver, Inc. v. General Shaver Corp., 21 F. Supp. 718 (D. Conn. 1937) (preliminary injunction denied).

77 See 3 Barron \& Holtzoff, Federal Practice \& Procedure § 1433, at 492-93 (Wright ed. 1958).

78 Compare text accompanying notes $34-41$ supra.

79200 F. Supp. 217 (D.R.I. 1961).

$80 \mathrm{Id}$. at 218. 1954).

81 See Nadya, Inc. v. Majestic Metal Specialties, Inc., 127 F. Supp. 467 (S.D.N.Y. 1961).

82 See Superior Elec. Co. v. General Radio Corp., 194 F. Supp. 339, 343 (D.N.J.

83 See, e.g., Owens v. American Sterographic Corp., 116 F. Supp. 406 (S.D.N.Y. 1953) ; Collins v. Wallin, 66 F. Supp. 687 (D. Mass. 1946) ; Eskimo Pie Corp. v. Arctic Fruit Ices, Inc., 15 F.2d 853 (E.D.N.Y. 1926). See also Sinko v. Casco, 89 F.2d 916 (7th Cir. 1937) ; Penmac Corp. v. Falcon Pencil Corp., 62 F. Supp. 358 (S.D.N.Y. 1958). 
But, except for these two infrequent types of injury, present judicial attitudes generally bar findings of irreparable injury to support preliminary equity relief by either injunction or bond.

Despite this restrictive trend in the requirements for preliminary injunctions, the more traditional Grand Rapids view ${ }^{84}$ has retained vitality in the Sixth Circuit. For example, Mueller v. Wolfinger, ${ }^{85}$ asserting that "general principles of equity which control the granting or refusing of preliminary injunctions apply in patent [infringement] suits," 88 resolved a doubt as to infringement of plaintiff's clearly valid patent in favor of the plaintiff, but offered the defendant the option of posting a bond in lieu of the injunction. Similarly, Minnesota Mining \& Mfg. Co. v. Neisner Bros., ${ }^{87}$ without reference to general equitable principles, found infringement of a clearly valid previously adjudicated patent from conflicting affidavits and granted an injunction on plaintiff's bald assertion of irreparable injury. ${ }^{88}$ These results recall the less stringent nineteenth century practice.

In conjunction with the generally greater difficulty in obtaining preliminary relief, plaintiffs who have not otherwise established that their patent will be upheld upon a final trial no longer can substantiate validity by showing only that the defendant "copied" their patented devices. ${ }^{80}$ In Belding Heminway Co. v. Future Fashions, Inc., ${ }^{90}$ the Second Circuit reversed a preliminary injunction and found that even an exact copy does not prove the validity of a design patent. This rationale has also appeared in decisions denying injunctions for copying ordinary patents. ${ }^{21}$ The only recorded case during the last two decades granting a preliminary injunction without adjudication or acquiescence ${ }^{92}$ probably was decided upon an "estoppel" and not a "copying" rationale, since the defendant had originally acceded to the plaintiff's patent but then sold the infringing product through a closely related corporation.

\section{Suggested Approach}

Although title, validity, infringement, and irreparable injury have been the elements of a claim for preliminary relief for over 150 years, the

84 See text accompanying notes $42-44$ supra. 1948)

8568 F. Supp. 485 (S.D. Ohio 1946), appeal dismissed, 165 F.2d 844 (6th Cir. 1952)

$\dot{6} I d$. at 488; see Gordon Johnson Co. v. Hunt, 109 F. Supp. 571 (N.D. Ohio

87101 F. Supp. 926 (N.D. III. 1951).

88 Id. at 928. But see Artmoore Co. v. Dayless Mfg. Co., 100 F. Supp. 110 (N.D. IIl. 1951).

89 Compare text accompanying notes 51-60 supra.

90143 F.2d 216 (2d Cir. 1944) (per curiam); cf. Celebrity, Inc. v. Trina, 264 F.2d 956 (2d Cir. 1959); Williams Mfg. Co. v. United Shoe Mach. Corp., 121 F.2d 273 (6th Cir. 1941), aff'd, 316 U.S. 364 (1942). See also Sears, Roebuck \& Co. v. Stiffel Co., 376 U.S. 225 (1964).

01 See Zandelin v. Maxwell Bentley Mfg. Co., 197 F. Supp. 608 (S.D.N.Y. 1961); cf. American Safety Table Co. v. Schreiber, 269 F.2d 255, 261-68 (2d Cir. 1959).

02 Schaffer Belts Co. v. Trade Accessories, Inc., 53 F. Supp. 266 (S.D.N.Y. 1942). 
needed quantum of proof has varied, even at a given point in time. The customary purpose of a preliminary injunction is to preserve the status quo. ${ }^{93}$ This goal is feasible in areas where the injunction is primarily prohibitory, for example, one that merely restrains an alleged infringer from using a disputed trademark until after the trial..$^{94}$ But a preliminary injunction in a patent suit tends to cause greater dislocation, since it frequently requires the defendant to "suspend" a substantial investment until the trial on the merits.95 Clearer articulation of the actual requirements for preliminary relief should supplant the old rubrics.

\section{No Reasonable Doubt}

The strongest possible case for preliminary relief obviously occurs if all elements are established beyond a reasonable doubt. The presence or absence of "no reasonable doubt" concerning title-shown by patent or assignment-and validity-presumed from a prior federal court adjudication ${ }^{96}$-is readily ascertainable by objective standards. Even the more subjective determination of infringement has evoked judicial verbalization that it must be "beyond question" 97 or "palpably and obviously clear" 98 alternatives to "no reasonable doubt." This showing of infringement is fulfilled if, without construction of opposing affidavits, the defendant's device can be shown substantially to conform to the one challenged in the

93 See, e.g., Doeskin Prods, Inc. v. United Paper Co., 195 F.2d 356 (7th Cir. 1952) ; Hoeme v. Jeoffroy, 100 F.2d 225 (5th Cir. 1938); Hershel Cal. Fruit Prods. Co. v. Hunt Foods, Inc., 111 F. Supp. 732, 734 (N.D. Cal. 1953) ; 7 Moore, Federial Practice \} 6 5 . 0 4 \text { (2d ed. 1955). }

The term "status quo" ordinarily refers to the last actual peaceable, noncontested status of the parties to the controversy which preceded the pending suit and which should be preserved until a final decree can be entered.

The preservation of status quo should not be confused with the economic stabilization of a whole industry, as compared with the restoration or attempted restoration of competition within such industry.

Hershel Cal. Fruit Prods. Co. v. Hunt Foods, Inc., supra at 734. See also Note, Temporary Injunctive Relief Under Section 10(l) of the Taft-Hartley Act, $111 \mathrm{U}$. PA. L. Rev. 460, 480 (1963).

94 See, e.g., Safeway Stores, Inc. v. Safeway Properties, Inc., 307 F.2d 495 (2d Cir. 1962) ; Selchow \& Righter Co. v. Western Printing \& Lithographing Co., 112 F.2d 430 ( 7 th Cir. 1940). Similarly, preliminary injunctions are granted upon a "prima facie" showing of copyright infringement without a showing of irreparable injury. See, e.g., Rushton v. Vitale, 218 F.2d 434, 436 (2d Cir. 1955); American Code Co. v. Bensinger, 282 Fed. 829, 835 (2d Cir. 1922) ; Royalty Designs, Inc. v. Thrifticheck Serv. Corp., 204 F. Supp. 702 (S.D.N.D. 1962) ; cf. Boosey v. Empire Music Co., 224 Fed. 646 (S.D.N.Y. 1915) (bond in lieu of injunction).

95 "[W]hile ordinarily a preliminary injunction aims to preserve the status quo pending suit, in a patent case like this it may be said to destroy it." A. B. Dick Co. v. Barnett, 277 Fed. 423, 425 (2d Cir. 1921).

$96 \mathrm{~A}$ determination of validity in one suit is not conclusive upon a subsequent suit upon the same patent between different parties. Triplett v. Lowell, 297 U.S. 638, 642-48 (1936); Aghnides v. Holden, 226 F.2d 949 (7th Cir. 1955). See also Staff of Subcomm. on Patents, Trademarks \& Copyrights, Senate Comm. on the Judiciary, 86Th Cong., 2d Sess., An Analysis of Patent Litigation Statistics 5 (Comm. Print 1961).

97 See Pacific Cage \& Screen Co. v. Continental Cage Corp., 259 F.2d 87 (9th

Cir. 1958); Heyman Mfg. Co. v. Electrix Corp., 200 F. Supp. 217 (D.R.I. 1961).

98 Collins v. Wallin, 66 F. Supp. 687 (D. Mass. 1946). 
prior adjudication of validity relied upon by plaintiff. ${ }^{99}$ Similarly subjective is an estimation that neither a permanent injunction nor damages will cure plaintiff's injury. To demonstrate such irreparable injury plaintiff must convince the court either that by the time of permanent injunction his business will be irretrievably lost or that the strong probability of defendant's insolvency in the near future destroys the value of the ultimate award of damages plaintiff expects. If plaintiff's market position is substantial, he probably will not be able to show that the alleged infringer's activity over the next few years will alone cause irreparable loss of market position. ${ }^{100}$ Moreover, if both plaintiff and defendant are economically viable entities an accounting for infringement may amply compensate the plaintiff for his loss of monopoly power until final decision on the merits. A defendant carrying on a substantial business will probably be able to respond to any judgment for damages. Therefore, a showing of irreparable injury should occur in only those few situations involving either a demonstrably weak plaintiff or defendant. No preliminary injunction case reported in the past two decades has contained such a showing. ${ }^{101}$

Even if the plaintiff's claim for relief is validated beyond a reasonable doubt, courts still may exercise their "sound discretion" to deny an injunction. Courts should not limit plaintiff to a bond instead of an injunction because of defendant's contention that harm to him is as great as that to the plaintiff. If all elements are proven without reasonable doubt, a preliminary injunction should be withheld in favor of bond only in cases of disproportionately severe injury to defendant ${ }^{102}$ or of extreme public hardship. ${ }^{103}$

\section{Reasonable Cause To Believe}

Plaintiffs who cannot establish each element of their case beyond a reasonable doubt should not be foreclosed from preliminary injunctive relief if there is only "reasonable cause to believe" part of the case. Title should always be held to a "no reasonable doubt" standard, because drastic relief seems inappropriate if title is questionable. Moreover, if there is only "reasonable cause to believe" more than one of the other elements, preliminary injunctive relief should be denied. If each of the four elements of plaintiff's claim was established beyond reasonable doubt, the probability of plaintiff's overall success at the final trial is very nearly as certain. Thus, if the court were " 99 percent sure" that each element existed given

99 See Claude Neon Lights, Inc. v. Gardner Sign Co.; 39 F.2d 487 (W.D. Pa. 1929) ; Radio Corp. of America v. Collins Radio Co., 13 F. Supp. 976 (D. Del. 1936). See also Western Elec. Co. v. Cinema Supplies, Inc., 80 F.2d 106 (8th Cir. 1935). 1961).

100 Superior Elec. Co. v. Gen. Radio Corp., 194 F. Supp. 339, 343, 347 (D.N.J.

101 But cf. Minnesota Mining \& Mfg. Co. v. Neisner Bros., 101 F. Supp. 926 (N.D. IIl. 1951).

102 See cases cited notes 130-31 infra.

103 See cases cited notes $132-35$ infra. 
the circumstances proven by the plaintiff, the court could be confident that the necessary combination of the four elements could also be demonstrated. However, if a court has only "reasonable cause to believe" an element exists, there is substantial, though not controlling, doubt about the result at trial. The likelihood that two elements proven to this lesser degree of certainty have occurred in combination is appreciably less than that either has occurred individually. Thus, if the claim of validity is based only on public acquiescence, then the court must both construe the unadjudicated patent's scope and determine whether defendant infringed the patent as construed. Unless the devices are virtually identical, affirmative findings of both validity and infringement would not support a conclusion of "reasonable cause to believe" that a valid patent has been infringed.

Since it is proper to grant preliminary relief if one of the necessary elements is established under a "reasonable cause to believe" standard while the others are proven "with no reasonable doubt," a close analysis of the former standard follows.

\section{a. Validity}

A "reasonable cause to believe" that the patent is valid arises from a showing of "public acquiescence"-clear proof that knowledgeable people refrained from infringing because of the probability of the patent's validity. ${ }^{104}$ Any lesser showing of validity would have to rely on the bare statutory presumption of validity, which simply shifts the burden of persuasion but lacks probative force to demonstrate reasonable cause to believe that the patent is valid. ${ }^{105}$ However, in this circumstance many courts have awarded plaintiffs preliminary injunctions when defendants have blatantly copied. ${ }^{106}$ But even exact duplication may be simply a "challenge to monopoly boldly asserted by the infringer on behalf of himself and the public," 107 and it certainly does not strengthen the statutory presumption of validity sufficiently to support preliminary relief. ${ }^{108}$ If the unfairness of the defendant's conduct moves a court of equity to grant injunctive relief to dispel defendant's unreasonable advantage, the court should accurately characterize its result as following from an estoppel of the defendant. ${ }^{109}$ The analogous doctrine in the law of unfair competition prevents a person who has stolen a trade secret from using it, even after its public dissemina-

104 See generally notes $22-26$ supra and accompanying text.

10535 U.S.C. $\S 282$ (1958).

106 See cases cited note 58 supra.

107 Williams Mfg. Co. v. United Shoe Mach. Corp., 121 F.2d 273, 277 (6th Cir. 1941), aff'd, 316 U.S. 364 (1942). See also Sears, Roebuck \& Co. v. Stiffel Co., 376 U..S. 225 (1964).

108 See Zandlin v. Maxwell Bentley Mfg. Co., 197 F.Supp. 608 (S.D.N.Y. 1961) (preliminary injunction under patent statute and common-law unfair competition denied; preliminary injunction granted under the Lanham Act). 1942).

109 Cf. Schaffer Belts, Inc. v. Trade Accessories, Inc., 53 F. Supp. 266 (S.D.N.Y. 
tion by a patent that is subsequently held invalid, so that it is available to all the world except this wrongdoer. ${ }^{110}$

\section{b. Infringement}

A court may have "reasonable cause to believe" that the plaintiff's patent has been infringed on the basis of affidavits submitted by both sides to construe the bounds of the patent. ${ }^{111}$ This finding most commonly occurs when the complainant relies upon a previously adjudicated patent so that the court also has before it the scope defined in prior litigation. In some cases, a substantial doubt that defendant's device is infringing may also cast suspicion on plaintiff's claim that he will be irreparably injured by the defendant driving him out of business, since significantly different devices are less likely to be economic substitutes. ${ }^{112}$

\section{c. Irreparable or Comparative Injury}

Even if title, validity, and infringement are proven with "no reasonable doubt," the plaintiff should not receive equity relief without at least a preliminary showing of "reasonable cause to believe" that he will suffer irreparable injury. If his case on the merits had been conclusive, he would have won an injunction on summary judgment.113 "Reasonable cause to believe" irreparable injury by loss of market position or defendant's financial insolvency is not readily generalized into an abstract test; predicting the shifting fortunes of apparently viable businesses like the plaintiff's or defendant's for the interval until trial is a highly speculative basis for judicial action. However, certain recurring situations illustrate showings of "reasonable cause to believe" that irreparable injury will occur.

Unless a plaintiff patentee who makes and sells his patented product is much smaller than the defendant infringer, he probably will not be able to prove the irreparable loss of market position that he expects upon denial of preliminary injunction. But if the court has "no reasonable doubt" that he will recover upon a final trial, it should try to deter overreaching infringers from capitalizing on the unpredictable amount of his injury. Due to the strict standards of proof in a judicial accounting, ${ }^{114}$ it is an oversimplification to assume that the plaintiff can be completely compensated for the defendant's infringement despite a successful trial on the merits. Especially elusive is a measure of full compensation that isolates from the

110 See Note, Relief in Trade Secret Cases After Patent Publication, 5 Patent, Tradediark \& Copyright J. of Research \& Education 70 (1962). See also TuRner, LAW OF TRADE SECRETS 437-59 (1962); Maruchnics, Industrial Trade Secrets, Their Use and Protection, 4 Clev.-Miar. I. Rev. 69 (1955).

111 See Minnesota Mining \& MIfg. Co.vi. Neisner Bros., 101 F. Supp. 926 (N.D. Ill. 1951) ; Schick Dry Shaver, Inc. v. Motoshaver, Inc., 21 F. Supp. 722 (S.D. Cal. 1937), aff'd, 100 F.2d 236 (1938).

$112 C f$. Mueller v. Wolfinger, 68 F. Supp. 485 (S.D. Ohio 1946), appeal dismissed, 165 F.2d 844 (6th Cir. 1948).

113 See Rubinstein v. Silex Co., 73 F. Supp. 336 (S.D.N.Y. 1947).

114 See Note, Recozery' in Patent Infringement Sitits, 60 Colcur. L. Rev. 840, 855-56 (1960). See also Note, Enforcement of Rights Against Patent Infringers, 72 HaRv. L. Rev. 328, 348-49 (1958). 
congeries of market influences the "intangible" loss of market position anticipated from the infringer's competition until trial. This loss generally cannot be brought within the traditional alternative damage tests of reasonable royalty, loss of patentee's profits, or profits made by the infringer. ${ }^{115}$

The probability of intangible loss to a plaintiff who "works" his patent, if supported by some credible evidence of loss of market position, should justify a presumption of "reasonable cause to believe" irreparable injury that warrants equity relief. Although the plaintiff's case is not strong enough for injunction, a court might not hesitate to offer the defendant the alternative of posting a bond to cover the eventual damages. A bond would not increase the plaintiff's eventual judgment, but it assures defendant's ability to pay. Moreover, the direct cost of the bond, ${ }^{116}$ the impact on defendant's credit standing, and the psychological deterrent of being immediately brought to task should prevent infringements of clearly valid patents to the extent that these infringements are encouraged solely by the expectation that plaintiff will never be able to recover his intangible losses.

If the patentee does not make or sell the patented article, but profits only from its "royalty value," courts need not presume "reasonable cause to believe" irreparable injury and enjoin or substitute a bond, even though every element except irreparable injury is established with "no reasonable doubt." This plaintiff will suffer no intangible loss of market position. He desires preliminary relief only to insure the extraction of high royalties, ${ }^{117}$ but a reasonable royalty for the infringing period should be recoverable as damages. 118 Therefore, the "good-faith" infringing defendant, especially one who has invested in plant and equipment in reliance on the legality of his actions, if financially solvent, should be able successfully to resist a preliminary injunction sought by a nonusing patentee.

115 See authorities cited note 114 supra. Although "the court may increase the damages up to three times the amount found or assessed," 35 U.S.C. \$284 (1958), the courts have used this provision not to compensate for "intangibles," but only to punish "willful infringers." See Note, Recovery in Patent Infringement Suits, 60 COLUM. L. REv. 840, 852-53 (1960).

118 "[T] he Surety companies require, save in exceptional cases, [negotiable securities, cash, or government bonds] . . . in an amount equal to the entire sum at risk." Fire, Casualty \& Surety Bulletins, Casualty \& Surety Section Bonds C-8 (3d printing Sept. 1948). If the defendant is considered to be an adequate risk, the cost may be $\$ 20$ per $\$ 1,000$ per annum, with a $50 \%$ reduction in premium if the face amount is fully secured by cash or United States government bonds. Ibid.; Interview With Representative of Standard Accident Insurance Company, Philadelphia, Pa., Feb. 26, 1964, who quoted from standard rates given by the Surety Association of America, New York, N.Y.

117 If the nonusing patentee took out his patent only to "block" technological advances of his competitors, arguably he is irreparably injured by the infringement. But regardless of whether he can show this "irreparable injury" with "no reasonable doubt," public policy would probably discourage a court of equity from enjoining the alleged infringer who attempts to design around this patent. See Powell, The Exclusive Right of the Patentee-Should the Right or Power To Exclude Others Be Dependent on Sale or Licensing by the Patentee?, 58 HARv. L. REv. 726 (1945). See also Precision Instrument Mfg. Co. v. Automotive Maintenance Mach. Co., 324 U.S. 806 (1945).

$848(1960)$. 
Another type of potential irreparable injury that is difficult to prove "beyond a reasonable doubt" flows from an infringement occurring when the plaintiff's seventeen-year monopoly has but a few years to run.119 Even if the patentee is successful in a final trial, a permanent injunction will be unavailable since his patent will then have expired. ${ }^{120}$ The infringer, who during a period of infringement became entrenched in his competitive position at the expense of the patentee, can continue to exploit this unlawful advantage. Thus, he has shortened the life of the patentee's monopoly by exchanging his liability for damages for a judicial compulsory license. Therefore, if the plaintiff can introduce some credible evidence to show that this competitive situation exists and if there is "no reasonable doubt" as to title, validity, and infringement, the court could reasonably presume that the plaintiff will sustain injury by this shortening of his monopoly beyond that curable by damages after a final trial. A preliminary injunction should be granted.

A patentee of an invention with such a short useful life that it will undoubtedly be worthless at the completion of the trial on the merits is not also entitled to this presumption of "reasonable cause to believe" irreparable injury. The owner of a novelty patent will not lose a continuing "intangible" market position after the final trial, since he will probably not then be exploiting his patent. In any case his permanent injunction will preclude the defendant from competition for the life of the patent. Moreover, this novelty patentee can recover damages for the intervening period like any other patentee, so his argument of irreparability should at most entitle him to a bond in lieu of injunction. Although the patent laws do not consider the social utility of patents in authorizing the relief available to the patentee, ${ }^{121}$ if this "one-price" aspect of the patent system should change, the limited usefulness of plaintiff's device would argue for less rather than more patent protection.

Incisive economic judgments are essential to the framing of appropriate orders. In addition, the freer use of bond in lieu of injunction could frequently provide greater flexibility in accommodating plaintiff's right to relief with the good-faith defendant's desire to avoid extreme financial hardship.

\section{Permanent Injunctive Relief Against Infringers}

\section{A. The Early Standards}

When a court of equity after full trial has found a patent valid and infringed, it must frame an adequate decree for relief. By the middle of the

110 See Staff of Subcomar. on Patents, Trademarks, \& Copyrights, Senate Comm. on the Judiciary, 86tr Cong., 2d Sess., An Analysis of Patent Litigation Statistics 3 (Comm. Print 1961).

120 See, e.g., Freedman v. Friedman, 242 F.2d 364 (4th Cir. 1957); Jordan v. Hemphill Co., 180 F.2d 457 (4th Cir. 1950) ; Hughes Tool Co. v. A. F. Spengler Co., 73 F. Supp. 156 (W.D. Okla. 1947), appeal dismissed, 169 F.2d 166 (10th Cir. 1948); cf. Royal-McBee Corp. v. Stmith-Corona Marchant, Inc., 295 F.2d 1 (2d Cir. 1961). 121 See text accompanying notes 9-11 supra. 
nineteenth century, courts generally recognized that the plaintiff was entitled to both an accounting for past damages ${ }^{122}$ and an injunction against future infringements for the life of the patent. ${ }^{123}$ Because the permanent injunction for the life of the patent ${ }^{124}$ was considered the only remedy ${ }^{125}$ adequate to protect the plaintiff's "right to exclude others from making, using or selling his invention," 126 it was often granted as a matter of course. ${ }^{127}$ However, the exercise of judicial discretion in equity gave rise to two exceptions in addition to the traditional equitable defenses of laches ${ }^{128}$ and estoppel. ${ }^{129}$

The first exception, based on the parties' relative injuries, permitted the court to stay the injunction and award only damages if the defendant could establish that his hardship under an injunction would materially outweigh the plaintiff's benefits, including his desire to preserve his statutory monopoly. ${ }^{130}$ For example, in Dorsey Harvester Revolving Rake Co. v. Marsh, ${ }^{131}$ since the plaintiff did not manufacture his device and the defendant in good faith had invested large sums that would be lost if he were enjoined, the court stayed the injunction and granted the plaintiff the usual damages for the loss of his statutory monopoly. In practical effect these decisions instituted judicial compulsory licensing by substituting for an injunction reasonable compensation for use of plaintiff's invention.

The second exception to the routine enjoining of infringers occurred when the court found that an injunction would sufficiently impair the

122 See Parks v. Booth, 102 U.S. 96 (188).

123 See, e.g., American Cotton-Tie Supply Co. v. McCready, 1 Fed. Cas. 631 (No. 295) (C.C.S.D.N.Y. 1879) ; Cook v. Ernest, 6 Fed. Cas. 385 (No. 3155) (D.C. D. La. 1872) ; Potter v. Mack, 19 Fed. Cas. 1166 (No. 11331) (C.C.N.D. Ohio 1868); Woodworth v. Stone, 30 Fed. Cas. 593 (No. 18021) (C.C.D. Mlass. 1845).

124 See, e.g., Bignall v. Harvey, 4 Fed. 334, 337 (C.C.N.D.N.Y. 1880) ; Jordan v. Dobson, 13 Fed. Cas. 1092 (No. 7519) (C.C.E.D. Pa. 1870). See also Westinghouse v. Carpenter, 43 Fed. 894 (C.C.S.D. Iowa 1888).

125 The courts have recognized their power to destroy the infringing articles but have not seen fit to resort to such a drastic remedy. See Note, Patents, Copyrights and Trade Secrets-Destruction of Infringing Instruments Ozoned by Infringer, 35 MICH. L. REv. 1350 (1937).

12635 U.S.C. § 154 (1958).

127 See cases cited notes 122-24 supra.

128 See, e.g., Imperial Chem. Mfg. Co. v. Stein, 69 Fed. 616 (C.C.S.D.N.Y. 1895), aff'd, 77 Fed. 612 (2d Cir. 1896) ; Atlantic Giant Potwder Co. v. Rand, 2 Fed. Cas. 147 (No. 626) (C.C.S.D.N.Y. 1879); Goodyear v. Honsingen, 10 Fed. Cas. 692 (No. 5572) (C.C.N.D. Ill. 1867). See also Gillons v. Shell Co., 86 F.2d 600 (9th Cir. 1936), cert. denied, 302 U.S. 689 (1937).

129 See Menendez v. Holt, 128 U.S. 514 (1888). See also Royal-MicBee v. Smith-Corona, Inc., 295 F.2d 1 (2d Cir. 1961).

130 See Barnard v. Gibson, 48 U.S. (7 How.) 649 (1849) ; Hoe v. Knap, 27 Fed. 204, 212 (C.C.N.D. Ill. 1886) ; Sanders v. Logan, 21 Fed. Cas. 321 (No. 12295) (C.C.W.D. Pa. 1861) ; Hoe v. Boston Daily Advertiser Corp., 14 Fed. 914, 916 (C.C.D. Mass. 1883) (dictum) ; cf. Colgate v. Western Union Tel. Co., 6 Fed. Cas. 85, 97 (No. 2995) (C.C.S.D.N.Y. 1878). But cf. Norton v. Eagle Automatic Can Co., 57 Fed. 929 (C.C.N.D. Cal. 1893) (preliminary injunction) ; Consolidated RollerMill Co. v. Coombs, 39 Fed. 803 (C.C.E.D. Mich. 1889).

1317 Fed. Cas. 939, 945 (No. 4014) (C.C.E.D. Pa. 1873); see MrcCrary v. Pennsylvania Canal Co., 5 Fed. 367 (C.C.E.D. Pa. 1880), aff'd, 141 U.S. 459 (1891). 
"public interest" to warrant money damages in lieu of injunction. ${ }^{132}$ The relative injuries to the parties then became irrelevant. In Bliss $v$. Brooklyn, ${ }^{133}$ the court accordingly denied an injunction because the withdrawal of the infringing hose couplings, which were "necessary for the daily use of the city in the prevention of fires," 134 would cause great public inconvenience. A modification of this rationale occurred in Thacher $v$. Mayor of Baltimore, ${ }^{135}$ where the court allowed the city to continue using the original infringing concrete structure but awarded the plaintiff damages and enjoined future infringements.

\section{B. Shifts in the Application of These Standards}

\section{Early Twentieth Century}

Electric Smelting \& Aluminum Co. v. Carborundum $\mathrm{Co}^{136}$ extended the Dorsey rationale to the situation in which both plaintiff and defendants were manufacturers in different industries. It stayed the injunction and only awarded damages since

it is not therefore the case of willful and deliberate entry by an infringer into competition with an established business . . . but it is the use in good faith of the Cowles process in a branch of industry which the patentee was not then and has not since occupied..$^{137}$

The vitality of the "nonuser" aspect of the "relative injuries to the parties" test was soon questioned and possibly destroyed in Continental Paper Bag Co. v. Eastern Paper Bag Co. (Paper Bag Patent Case). ${ }^{138}$ A manufacturer of paper bags, who had patented a machine for manufacturing bags, sued a competing manufacturer for infringement, although the patentee was not using the machine himself. After losing on the issues of validity and infringement, the defendant resisted an injunction on the rationale that the "public interest" required a patentee who admittedly intended neither use nor licensing of his patent to offer it to other manufacturers on reasonable terms. The Supreme Court, however, found nothing in the Constitution or the patent laws requiring denial of injunction because of nonuse:

We have seen that it has been the judgment of Congress from the beginning that the sciences and the useful arts could be best ad-

132 See Ballard v. City of Pittsburgh, 12 Fed. 783 (C.C.W.D. Pa. 1882). But see Thomson-Houston Elec. Co. v. Union Ry., 78 Fed. 365 (C.C.S.D.N.Y. 1896).

1333 Fed. Cas. 706 (No. 1544) (C.C.E.D.N.Y. 1871).

$134 \mathrm{Id}$. at 709.

135219 Fed. 909 (D. Md. 1915), aff'd, 230 Fed. 1022 (4th Cir. 1916).

130189 Fed. 710 (C.C.W.D. Pa. 1900), rev'd on other grounds, 203 Fed. 976 (3d Cir.), cert. denied, 231 U.S. 754 (1913).

$137 \mathrm{Id}$. at 713 .

138210 U.S. 405 (1908). Mr. Justice Harlan dissented on grounds of public policy. 
vanced by giving an exclusive right to an inventor. . . . Congress has not "overlooked the subject of non-user of patented inventions." . . . In some foreign countries the right granted to an inventor is affected by non-use. This policy, we must assume, Congress has not been ignorant of nor of its effects. It has, nevertheless, selected another policy; it has continued that policy through many years. We may assume that experience has demonstrated its wisdom and beneficial effect upon the arts and sciences. ${ }^{139}$

But the Court did note that the right to exclude the patentee's immediate competitor from using the invention was the most reasonable protection of the patent, ${ }^{140}$ and the Court carefully limited the decision to the situation of directly competing parties.

Despite these caveats, most courts accepted this case as generally limiting their power to refuse injunctions, at least in circumstances of plaintiff's nonuse of the patent. ${ }^{141}$ No court during the next three decades substituted a bond for a permanent injunction upon a "relative injuries" rationale. ${ }^{142}$ The Paper Bag Patent Case did not affect the availability of the "public injury" exception. ${ }^{143}$

\section{Middle Twentieth Century}

Two cases decided during the nineteen thirties seemed to recognize the Electric Smelting line of cases denying an injunction against a noncompeting user of the device. In Curtiss Aerocar Co. v. Springer, ${ }^{144}$ the court refused to enjoin a defendant who was using a car that infringed the plaintiff's patent, provided the defendant paid damages to the plaintiff. Similarly, in Nerney v. New York, N.H. \& H.R.R., ${ }^{145}$ an injunction was conditioned on nonpayment of damages by the defendant railroad using infringing coupling devices. Despite these two cases, however, permanent injunctions continued to be granted as a matter of course. ${ }^{146}$

$139 I d$. at $429-30$.

140 Ibid.

141 See cases cited note 150 infra.

142 But cf. Landis Tool Co. v. Ingle, 286 F.2d 5 (3d Cir. 1923) (preliminary injunction).

143 See Thacher v. Mayor of Baltimore, 219 Fed. 909 (D. Md. 1915), aff'd, 230 Fed. 1022 (4th Cir. 1916).

14481 F.2d 668 (5th Cir. 1936). See American Safety Device Co. v. Kurland Chem. Co., 68 F.2d 734 (2d Cir. 1934) (dictum).

14583 F.2d 409 (2d Cir. 1936).

146 See, e.g., J. R. Clark Co. v. Jones \& Laughlin Steel Corp., 186 F. Supp. 22, 28-29 (S.D. Ind. 1960), aff'd, 288 F.2d 279 (1961); R. Wallace \& Sons Mfg. Co. v. Ellmore Silver Co., 91 F. Supp. 703, 705 (D. Conn. 1950) ; Minnesota Mining \& Mfg. Co. v. Pax Plastics Corp., 65 F. Supp. 303 (N.D. Ill. 1946), aff'd, $159 \mathrm{~F} .2 \mathrm{~d}$ 554 (7th Cir. 1947) ; Balban v. Polyfoto Corp., 47 F. Supp. 472, 480 (D. Del. 1942); Barnett v. F. W. Woolworth Co., 56 F.2d 418 (S.D.N.Y. 1931), aff'd, 56 F.2d 420 (2d Cir. 1932). But cf. Condenser Corp. of America v. Micamold Radio Corp., 145 F.2d 878 (2d Cir. 1944), cert. denied, 324 U.S. 861 (1945). 
In Special Equip. Co. v. Coe, ${ }^{147}$ the Supreme Court did not rule on an argument by the Commissioner of Patents that the patent in question should not issue because the patentee intended to suppress it, since the evidence failed to establish this intention. ${ }^{148}$ However, three dissenting justices would have found intent to suppress and would have outlawed it by overruling the Paper Bag Patent Case as inconsistent with the Constitution and the patent laws. ${ }^{149}$ But this dissent has not generated further judicial questioning of the Paper Bag nullification of the "relative injuries" test during the subsequent two decades. ${ }^{150}$

The "public interest" exception to the automatic enjoining of infringers is probably still available to courts. For example, in City of Milwaukee v. Activated Sludge, Inc., ${ }^{151}$ the Seventh Circuit dissolved an injunction that would have affected the sewage disposal for the city of Milwaukee to avoid endangering the public health and safety. ${ }^{152}$

\section{A Suggested Standard}

The Paper Bag Patent Case, favoring broad protection of statutory patent monopolies, removed most of the federal courts' discretion to refuse permanent injunctions on the basis of the parties' comparative injuries. ${ }^{153}$ A plaintiff should now always receive a permanent injunction upon proof of infringement of his valid patent, unless the defendant can bring himself within one of the narrow exceptions permitting denial of this relief.

\section{Grossly Disparate Hardship}

Despite the usual disregard of the parties' comparative injuries, a court of equity should mitigate the harsh public policy of enjoining all infringements by retaining at least the limited discretion to deny some injunctions that impose severe hardship on the infringer, if only slight injury to the

147324 U.S. 370 (1945).

148 Id. at 375 .

149 Id. at 381 (Douglas, Black, and Murphy, JJ., dissenting); see Powell, The Exclusive Right of the Patentee-Should the Right or Power To Exclude Others Be Dependent on Sale or Licensing by the Patentee?, 58 HARv. L. REv. 726 (1945); 93 U. PA. L. Rev. 456 (1945). See generally Frost, Legal Incidents of Non-Use of Patented Inventions Reconsidered, 14 GEO. WASH. L. REv. 273 (1946).

160 See, e.g., Well Surveys, Inc. v. McCullough Tool Co., 199 F. Supp. 374 (N.D. Okla. 1961); Hartford Nat'I Bank \& Trust Co. v. E. F. Drew \& Co., 188 F. Supp. 353 (D. Del. 1960), aff'd, 290 F.2d 589 (3d Cir.), cert. denied, 368 U.S. 825 (1961); Zysset v. Popeil Bros., 167 F. Supp. 362 (N.D. IIl. 1958), aff'd, 276 F.2d 354 (7th Cir.), cert. denied, 364 U.S. 826 (1960). "It is well settled that it is the exclusive privilege of the owner of a patent monopoly to permit the use of his patent or deliberately keep his invention out of use during the life of the patent regardless of his motive." Leuschner v. Kuther, 314 F.2d 71, 73 (9th Cir. 1963).

15169 F.2d 577 (7th Cir.), cert. denied, 293 U.S. 576 (1934).

152 Accord, Cincinnati Car Co. v. New York Rapid Transit Corp., 37 F.2d 100 (2d Cir. 1930) (per curiam); cf. Nerney v. New York, N.H. \& H.R.R., 83 F.2d 409, 411 (2d Cir. 1936). But cf. Electro Bleaching Gas Co. v. Village of Garden City, 33 F.2d 209 (S.D.N.Y. 1926).

153 Continental Paper Bag Co. v. Eastern Paper Bag Co., 210 U.S. 405 (1908). 
patentee would ensue. The court's inquiry might balance the loss to the defendant's existing investment against the loss of plaintiff's expected profits, and also investigate the defendant's good faith and possible suppression of the patent by the plaintiff.

In the Paper Bag Patent Case, involving competing manufacturers, the nonusing patentee might have suffered substantial injury if his infringing competitor used the patented device. The patentee's desire to suppress the patent to avoid competitive injury-a legitimate use of his patent position under existing law ${ }^{154}$-was properly respected. Similarly, if the defendant's infringing activity is the repeated sale of the patented device, denial of injunction effectively enforces a compulsory license upon the patentee and emasculates his statutory "right to exclude" by preventing negotiation of satisfactoy licensing agreements thereafter. This injury also should sustain an injunction regardless of the magnitude of injury to the infringer. But a patentee who is not a manufacturer or who does not manufacture in the defendant's field ${ }^{155}$ will suffer no harm to his underlying business interest if he is forced to license the device for defendant's use on reasonable terms, including a component of monopoly profit. If the goodfaith infringer uses the patented item but does not offer it for sale, the plaintiff's harm, if injunction were denied, would be confined to his inability to extract royalties from the defendant beycnd the amount allowed by the court. In this circumstance a court might justifiably refuse an injunction that would severely harm the defendant-such as one that would render worthless an expensive device or system innocently made only for defendant's own use, but which later is found to incorporate a feature that infringes plaintiff's patent. The plaintiff's right to enjoin other potential and actual infringers would not be curtailed.

\section{The Public Interest}

Use of the vague phrase "public interest" rarely substantiates the appropriateness of a decision. In fact the congressional mandate to enjoin patent infringements focused judicial attention in early patent cases on the rights of the parties with little emphasis on "public interest" extrinsic to the patent laws. ${ }^{156}$ But under the twentieth century view, "courts of equity may appropriately withhold their aid where the plaintiff is using the right asserted contrary to the public interest . . . ."157

154 See Leuschner v. Kuther, 314 F.2d 71, 73 (9th Cir. 1963).

155 See cases cited notes 130-31 supra.

156 See Sickels v. Tileson, 22 Fed. Cas. 77 (No. 12837) (C.C.S.D.N.Y. 1857) (preliminary injunction); cf. Heaton-Peninsular Button Fastener Co. v. Eureka Specialty Co., 77 Fed. 288, 294 (6th Cir. 1896).

157 Morton Salt Co. v. G. S. Suppiger Co., 314 U.S. 488, 492 (1942). See generally Staff of Subcomm. on Patents, Trademarks \& Copyrights, Senate Comm. on the Judiciary, 86th CoNg., 2D Sess., Compulsory Licensing Under AnTi-Trust Judgments (Comm. Print 1960); Folk, The Relation of Patents to the Antitrust Lazes, 13 Law \& Contemp. Prob. 278 (1948) ; Nicoson, Misuse of the Misuse Doctrine in Infringement Suits, 9 U.C.L.A.L. Rev. 76 (1962). 
Only the specific context of litigation can give content to the "public interest" protected by denying an injunction. Decisions concerning "misuses" of patents as in industry-wide price fixing under a patent license, ${ }^{168}$ or through licensing agreements tied to the purchase or license of other articles, ${ }^{159}$ accommodate the patent laws to the antitrust laws under the "public interest" rubric to deprive a wrongdoing patentee of both injunction and damages against an equally reprehensible infringer. In Morton Salt Co. v. G. S. Suppiger Co., ${ }^{160}$ the patentee leased his patented machines on condition that only his salt tablets be used in them. This abuse of the patent monopoly-protecting a market for another unpatented product-disqualified the patentee from maintaining an infringement suit, "regardless of whether the particular defendant has suffered from the misuse of the patent." 161

But "public interest" also has described considerations wholly internal to the patent laws. If an identifiable inconvenience to the public-such as widespread danger to health and safety caused by reconstruction of a public sewage facility ${ }^{162}$-would follow an injunction against the infringement, a court of equity might award the patentee only damages. Contrary to the "misuse" situation, the patentee has done nothing wrong to impel a court to withhold all relief. Rather, the court's task is to reconcile his relief with the public interest. The patentee's loss is not very substantial if the infringer is not a competitor but only a mere user from whom the plaintiff can recover monetary damages for the loss of his monopoly. The additional factor of great inconvenience then might overcome the patentee's statutory "right" to exclusive monopoly. The patentee's only remedy would be damages measured by a reasonable royalty.

However, the "public interest" concept does not authorize denial of injunction to all patentees who neither use nor permit use of their inventions, even on payment of reasonable royalties. ${ }^{163}$ "Nonuse" by a patentee, however undesirable in terms of general policy, is distinguishable both from patent "misuse" that affirmatively offends identifiable antitrust legislative policies and from determinable public inconvenience that may be balanced

158 See Newburgh Moire Co. v. Superior Moire Co., 237 F.2d 283 (3d Cir. 1956) ; cf. United States v. New Wrinkle, Inc., 342 U.S. 371 (1952); United States v. United States Gypsum Co., 333 U.S. 364 (1948) ; United States v. Line Material Co., 333 U.S. 287 (1948). But cf. United States v. General Elec. Co., 272 U.S. 476 (1926). See generally Nicoson, supra note 157; Oppenheim, Patents and Antitrust: Peaceful Coexistence, 54 Micr. L. Rev. 199 (1955).

159 See American Securit Co. v. Shatterproof Glass Corp., 154 F. Supp. 890 (D. Del.), aff'd, 268 F.2d 769 (1957). See also Mercoid Corp. v. Mid-Continent Inv. Co., 320 U.S. 661 (1944), and its legislative response, 35 U.S.C. $\$ 271$ (1958). See generally Note, Contributory Infringement and Misuse-The Effect of Section 271 of the Patent Act of 1952, 66 HARV. L. REv. 909 (1953).

160314 U.S. 488 (1942).

161 Id. at 494.

162 See City of Milwaukee v. Activated Sludge, Inc., 69 F.2d 577 (7th Cir.), cert. denied, 293 U.S. 576 (1934).

163 But see Special Equip. Co. v. Coe, 324 U.S. 370, 378 (1945) (Douglas, J., dissenting). 
by an equity court against the patentee's diminution of monopoly control. Any sanctions against nonuse generally are more properly addressed to Congress as a plea for compulsory licensing of unused patents.

\section{CONCLUSION}

The federal equity power in patent infringement suits has required increasingly more persuasive showings of title, validity, infringement, and irreparable injury to support temporary injunctive relief. Moreover, upon proof of title, infringement, and validity at final trial, courts have invariably granted permanent injunctions, save in the very narrow areas of grossly disparate harm and public inconvenience. The supposed impropriety of presently available injunctive relief ${ }^{104}$ has contributed to the myriad of unsuccessful compulsory licensing proposals ${ }^{165}$ generally addressed to removing the right to exclude by injunction from the patentee's arsenal of weapons. These proposals have included compulsory licensing of all patents ${ }^{166}$ and compulsory licensing of only those patents necessary for national defense or the public welfare. ${ }^{167}$ Imaginative exercise of present federal court power to grant "injunctions in accordance with the principles of equity" 168 has also been suggested to provide judicially dispensed compulsory licensing, applied flexibly depending upon the circumstances of the case. ${ }^{169}$ But except in areas of specific overriding public interest, the longentrenched stress on not impairing the patentee's right to exclude has overshadowed the diffused and disputed public interest in immediate introduction of all technological advances into the economy. Courts, justifiably reluctant to permit their own social and economic views to ameliorate the application of permanent injunctive relief, have left such revolutionary inroads to the legislature.

Herbert F. Schwartz

164 See Staff of Subcomm. on Patents, Trademarks \& Copyrights, Senate Comm. on the Judiciary, 85Th Cong., 2D Sess., AN Economic Review of the Patent System 44-80 (Comm. Print 1958). But see Staff of Subcomm. on Patents, Trademarks \& Copyrights, Senate Comar. on the Judiciary, 86th Cong., 2d Sess., The Patent System: Its Economic and Social Basis 20-25 (Comm. Print 1960).

165 See Staff of Subcomm. on Patents, Trademarks \& Copyrights, Senate Comm. on the Judiciary, 85th Cong., 2d Sess., Compulsory Licensing of Patents - A Legrslative History 1-27 (Comm. Print 1958). See also Staff of Subcomm. on Patents, Trademarks \& Copyrights, Senate Comm. on the Judiciary, 85th Cong., 2D Sess., Compulsory Licensing of Patents Under Some Non-AMERicaN Systears 1-51 (Comm. Print 1958).

${ }^{166}$ E.g., H.R. 9259, 75th Cong., 1st Sess. (1938) ; S. 2116, H.R. 8776, 62d Cong., 1st Sess. (1911). (1942).

167 E.g., H.R. 3762, 78th Cong., 2d Sess. (1943) ; S. 2303, 77th Cong., 2d Sess.

16835 U.S.C. $\$ 283$ (1958).

169 See Staff of Subcomm. on Patents, Trademarks \& Copyrights, Senate Comar. on the Judiciary, 84th Cong., 2d Sess., The Patent System and the MODERN ECONOMY 28-34 (Comm. Print 1957). Stedman, Invention and Public Policy, 12 Law \& Contemp. Prob. 649, 668-71 (1947). 